\title{
MODEL PEMBELAJARAN GENERATIF TERHADAP HASIL BELAJAR KIMIA PADA MATERI IKATAN KIMIA
}

\author{
Tiurlina Siregar ${ }^{1)}$; Mariana Nensi ${ }^{2)}$ \\ ${ }^{1}$ Program Studi Magister Pendidikan IPA UNCEN; tiurlina.siregar@yahoo.com \\ ${ }^{2}$ Program Studi Magister Pendidikan IPA UNCEN; mariananensi26@gmail.com
}

\begin{abstract}
Using conventional learning methods for students who get bored quickly and are not interested in chemistry lessons. These challenges require problem solving through the learning activities provided. Learning can be done with learning models that are appropriate to the characteristics of chemicals. One learning model that provides opportunities for participants to develop their knowledge through direct experience and indirect experience is the generative learning model. The sample in this study was class $\mathrm{X}$ as many as 34 people. The method in this research is the design of one group pretest posttest. The purpose of this study is to study and improve the learning outcomes of chemicals in chemical bonds (n-Gain) using generative learning models in automotive class $\mathrm{X}$ students of SMK Negeri 3 Jayapura. Learning that involves and enhances chemistry learning outcomes in chemical bonding materials (n-Gain) using generative learning models in automotive class X students of SMK Negeri 3 Jayapura with an average n-Gain value of RPP 1 of 0.62 , RPP 2 of 068 and RPP 3 are 0.79. The average $\mathrm{n}$-Gain value of RPP 1, RPP 2 and RPP 3 is 0.71 (high category).
\end{abstract}

Keywords : Model Generative; Chemical Bonds

\section{ASTRAK}

Penggunaan metode pembelajaran konvensional mengakibatkan peserta didik cepat bosan dan tidak tertarik pada pelajaran kimia. Kendala-kendala tersebut menuntut adanya pemecahan masalah melalui kegiatan belajar yang bermakna. Pembelajaran bermakna dapat dilakukan dengan model pembelajaran yang sesuai dengan karakteristik materi kimia. Salah satu model pembelajaran yang memberikan kesempatan kepada peserta untuk mengembangkan pengetahuannya melalui pengalaman langsung dan pengalaman tidak langsung yaitu model pembelajaran generatif. Sampel dalam penelitian ini kelas X sebanyak 34 orang. Metode dalam penelitian ini adalah one group pretest postest design. Tujuan penenelitian ini untuk mengetahui pengaruh dan peningkatan hasil belajar kimia pada materi ikatan kimia (n-Gain) yang menggunakan model pembelajaran generatif pada peserta didik kelas X otomotif SMK Negeri 3 Jayapura. Hasilnya terdapat pengaruh dan peningkatan hasil belajar kimia pada materi ikatan kimia (n-Gain) yang menggunakan model pembelajaran generatif pada peserta didik kelas $\mathrm{X}$ otomotif SMK Negeri 3 Jayapura dengan niali n-Gain rata-rata RPP 1 sebesar 0,62, RPP 2 sebesar 0,68 dan RPP 3 sebesar 0,79.Nilai n-Gain rata-rata dari RPP 1, RPP 2, dan RPP 3 sebesar 0,71 ( kategori tinggi ).

Kata Kunci : Model Generatif; Ikatan Kimia

\section{PENDAHULUAN}

Pendidikan menengah terdiri atas
pendidikan menengah umum dan
pendidikan menengah kejuruan yaitu

Sekolah Menengah Atas (SMA), Sekolah
Menengah Kejuruan (SMK). Sekolah Menengah Kejuruan terbagi menjadi 15 jurusan yaitu Jurusan Administrasi Perkantoran, Jurusan Akuntansi, Jurusan Perbankan, Jurusan Marketing/Pemasaran, 
Jurusan Jurnalistik, Jurusan Animasi, Jurusan Multimedia, Jurusan Tata Busana, Jurusan Perhotelan, Jurusan Pariwisata, Jurusan Teknik Otomotif, Jurusan Teknik Elektronika, Jurusan Farmasi, Jurusan Analisis Kimia. di SMK terbagi dalam beberapa bidang keahlian salah satunya kelompok teknologi dan rekayasa yang merupakan bidang keahlian di SMK Negeri 3 Jayapura. Bidang keahlian teknologi dan rekayasa terbagi menjadi 10 jurusan yaitu jurusan Program Keahlian Studi Bangunan, Program Keahlian Studi Elektronika, Program Keahlian Studi Pemanfaatan Ketenagalistrikan, Program Keahlian Studi Mesin, Program Keahlian Studi Otomotif, Program Keahlian Studi Geologi Pertambangan, Program Keahlian Studi Survey dan Pemetaan, Program Keahlian Studi Plambing dan Sanitasi, Program Keahlian Studi Komputer dan Informatika Dan Program Keahlian Studi Energi Terbarukan. Jurusan Program Keahlian Studi Otomotif adalah salah satu bidang kejuruan di SMK yang mempelajari mata pelajaran kimia.

Kimia adalah salah satu cabang Ilmu Pengetahuan Alam (IPA) yang mempelajari tentang materi, meliputi struktur, sifat, susunan dan perubahan materi yang menghasilkan zat baru serta energi yang menyertainya. Pelajaran kimia menitik beratkan pada penguasaan konsep dan prinsip dasar ilmu dan teknologi yang dapat diterapkan dalam kehidupan sehari- hari yang melandasi kompetensi untuk bekerja. Materi-materi yang dipelajari dalam ilmu kimia memiliki karakteristik konsep yang bersifat konkret hingga abstrak.Mata pelajaran kimia di SMA berbeda dengan SMK, hal ini disebabkan kimia merupakan mata pelajaran adaptif yang diperlukan untuk penunjang kompetensi keahlian di SMK. Tujuan diberikannya mata pelajaran kimia adalah agar peserta didik memiliki pemahaman yang menjadi dasar untuk menunjang kompetensi keahlian pada teknik otomotif (Ana Setianingsih, 2018).

Berdasarkan pengamatan awal di SMK Negeri 3 Jayapura terdapat beberapa kendala yang dapat mempengaruhi hasil belajar kimia diantaranya minat belajar peserta didik rendah, pemahaman materi yang sulit, peserta didik menganggap tidak sesuai dengan bidang keahlian yang di miliki, dan umumnya di ajarkan dengan menggunakan metode pembelajaran konvensional dan tanpa ada praktikum sementara SMK Negeri 3 Jayapura. Penggunaan metode pembelajaran konvensional mengakibatkan peserta didik cepat bosan dan tidak tertarik pada pelajaran kimia. Kendala-kendala tersebut menuntut adanya pemecahan masalah melalui kegiatan belajar yang bermakna. Pembelajaran bermakna dapat dilakukan dengan model pembelajaran yang sesuai dengan karakteristik materi kimia. Salah satu model pembelajaran yang 
\begin{tabular}{l|l} 
Jurnal Ilmu Pendidikan Indonesia 8 (1) : 1 - 10 & 3
\end{tabular}

memberikan kesempatan kepada peserta untuk mengembangkan pengetahuannya melalui pengalaman langsung dan pengalaman tidak langsung yaitu model pembelajaran generatif. (Wena. M, 2008):

1. Model Pembelajaran generatif dapat diterapkan dalam mata pelajaran kimia karena mampu membantu peserta didik dalam mengkonstruksi atau membangun pengetahuan secara mandiri. Model pembelajaran generatif memiliki tahapan pembelajaran yaitu : tahap orientasi, tahap pengungkapan ide, tahap tantangan, dan tahap penerapan. Beberapa tahapan pembelajaran tersebut mampu memberikan suasana emosional yang positif kepada peserta didik selama proses pembelajaran berlangsung, hal ini mempengaruhi hasil belajar peserta didik. Model pembelajaran generatif pada pembelajaran sains akan dapat menciptakan suasana pembelajaran yang menyenangkan, dalam hal ini peserta didik mendapat kebebasan dalam mengajukan ide-ide masalah serta mendiskusikan konsep kimia tanpa dibebani rasa takut, serta peserta didik dapat berargumentasi sampai pada penguasaan konsep. Model pembelajaran generatif dapat menyelesaikan permasalahan dalam pembelajaran kimia, karena dalam model pembelajaran ini peserta didik tidak hanya dituntun untuk membangun pengetahuan sendiri, tetapi guru diharapkan dapat memberikan suasana emosional yang positif kepada peserta didik selama pembelajaran berlangsung sehingga tujuan akhir pembelajaran dapat tercapai dengan adanya pengaruh hasil belajar peserta didik. Tujuan penelitian adalah untuk mengetahui Pengaruh dan peningkatan model pembelajaran generatif terhadap hasil belajar kimia pada materi ikatan kimia peserta didik kelasX otomotif SMK Negeri 3 Jayapura.

Model Pembelajaran generatif dapat sebagai solusi terhadap pembelajaran kimia yang di hadapi oleh SMK Negeri 3 Jayapura. Hal tersebut di dukung oleh penelitian yang di lakukan oleh Wulansari dkk yang menyatakan bahwa penggunaan model pembelajaran generatif dapat meningkatkan pemahaman dan hasil belajar akuntasi pada peserta didik kelas XI IPS 1 SMA Negeri 1 Surakarta tahun ajaran 2013/2014.

Berdasarkan beberapa alasan tersebut, maka penulis telah melakukan penelitian dengan judul "Pengaruh Model Pembelajaran Generatif Terhadap Hasil Belajar Kimia Pada Materi Ikatan Kimia" METODE PENELITIAN

Jenis Penelitian ini quasi experimental dengan jenis pretest dan 
posttest. Design penelitian ini adalah one group pretest postest design.

$$
\mathrm{O}_{1} \times \mathrm{O}_{2}
$$

Keterangan :

$\mathrm{O}_{1}$ menyatakan hasil pengukuran awal kelas eksperimen (pretest), $\mathrm{O}_{2}$ menyatakan hasil Pengukuran akhir kelas eksperimen (posttest), dan $\mathrm{X}$ menyatakan Perlakuan yang dilakukan untuk kelas eksperimen menggunakan model pembelajaran generatif.

Desain ini mempunyai kelompok kontrol, tetapi tidak dapat berfungsi sepenuhnya untuk mengontrol variabelvariabel luar yang mempengaruhi pelaksanaan eksperimen. Quasi experimen design, digunakan karena pada kenyataannya sulit mendapatkan kelompok kontrol yang digunakan untuk penelitian. Data kuantitatif pada penelitian ini berbentuk Pretest-Postest yang kemudian diolah untuk mengetahui hasil belajar peserta didik pada setiap indikator serta mengetahui apakah kenaikan ini sangat signifikan atau tidak setelah di terapkan model pembelajaran generatif.

\section{HASIL DAN PEMBAHASAN}

Sebelum melakukan penelitian menggunakan model pembelajaran generatif pada kelas eksperimen, dilakukan analisis terhadap perangkat tes yang akan digunakan yaitu berupa soal tes hasil belajar yang telah dipersiapkan sesuai dengan Rencana Pelaksanaan
Pembelajaran (RPP) dengan jumlah peserta didik 34 orang.

1) Uji Validitas dan Reabilitas Instrumen Instrumen di ujicobakan di SMK Negeri 2 Jayapura dengan jumlah responden 34 peserta didik dan di analisis terlebih dahulu sebelum diberikan pada kelas eksperimen. Untuk instrumen soal tes hasil belajar peserta didik yang di ujikan sebanyak 30 soal yang terdistribusi dalam 3 RPP, dan di dapatkan soal yang valid pada RPP 1 sebanyak 8 soal, RPP 2 sebanyak 7 soal, dan RPP 3 sebanyak 8 soal. Untuk Analisis reabilitas menggunakan rumus Spearman Brown bertujuan untuk mengetahui kelayakan dari soal tes tersebut sebelum digunakan dalam pengambilan data. Instrumen dapat dikatakan reliabel dengan melihat kriteria uji antara $r_{\text {hitung }}$ dengan $r_{\text {tabel}}$, apabila $\mathrm{r}_{\text {hitung }}\left(\mathrm{r}_{11}\right)>\mathrm{r}_{\text {tabel }}$ maka instrumen memenuhi kriteria uji. Nilai $r_{\text {tabel }}(\mathrm{N}=34)$ yang digunakan sebesar 0,349 dengan tingkat kepercayaan $\alpha=95 \%$, sedangkan data yang diperoleh dari hasil uji statistik pada RPP $1 \mathrm{r}_{11}=0,507$, hasil uji statistik RPP II $r_{11}=0,522$ dan hasil uji statistik pada RPP III $r_{11}=0,512$ dengan demikian harga $\mathrm{r}_{11}>\mathrm{r}_{\text {tabel Kriteria }}$ uji tersebut menunjukkan bahwa tes hasil belajar dinyatakan reliabel atau dapat dipercaya untuk digunakan dalam pengambilan data.

1. Uji Regresi Model Pembelajaran Generatif Terhadap Hasil Belajar . 
Uji Regresi linier sederhana menggunakan software SPSS 22, diperoleh persamaan $\mathrm{Y}=20,719+7,391 \mathrm{X}$. Pengujian ini jika nilai signifikan $<0,05$ maka Ha di terima atau signifikan dan nilai signifikan > 0,05, maka Ha ditolak atau

tidak signifikan. Data pengujian hasil belajar dapat di lihat pada Tabel 2 berikut: Tabel 2. Uji taraf signifikan hasil belajar RPP 1, RPP 2, dan RPP 3

\begin{tabular}{|c|c|c|}
\hline $\begin{array}{c}\text { Hasil } \\
\text { Belajar }\end{array}$ & $\begin{array}{c}\text { Nilai } \\
\text { Signifikan }\end{array}$ & \multicolumn{1}{|c|}{ Keputusan } \\
\hline 1,2 dan 3 & 0,00 & $\begin{array}{l}\text { Terdapat pengaruh yang } \\
\text { signifikan }\end{array}$ \\
\hline
\end{tabular}

\section{Hasil ujit-test}

Tabel 3 Uji t-test nilai rata dari RPP 1, RPP 2 dan RPP 31

\begin{tabular}{|c|c|c|c|c|c|c|c|c|c|}
\hline \multicolumn{10}{|c|}{ Paired Samples Test } \\
\hline & & \multicolumn{5}{|c|}{ Paired Differences } & \multirow{3}{*}{$\mathrm{t}$} & \multirow{3}{*}{ Df } & \multirow{3}{*}{$\begin{array}{l}\text { Sig. (2- } \\
\text { tailed) }\end{array}$} \\
\hline & & \multirow{2}{*}{ Mean } & \multirow{2}{*}{$\begin{array}{c}\text { Std. } \\
\text { Deviation }\end{array}$} & \multirow{2}{*}{$\begin{array}{c}\text { Std. Error } \\
\text { Mean }\end{array}$} & \multicolumn{2}{|c|}{$\begin{array}{l}\text { 95\% Confidence Interval of } \\
\text { the Difference }\end{array}$} & & & \\
\hline & & & & & Lower & Upper & & & \\
\hline Pair 1 & $\begin{array}{l}\text { nilai pretest - } \\
\text { nilai postest }\end{array}$ & $\begin{array}{r}- \\
3494047675.6 \\
4516\end{array}$ & $\begin{array}{r}2863876273 . \\
02863\end{array}$ & $\begin{array}{r}51436736 \\
2.98462\end{array}$ & $\begin{array}{r}4544525973 . \\
48884\end{array}$ & $\begin{array}{r}2443569377 . \\
80148\end{array}$ & $\begin{array}{r}- \\
6.793\end{array}$ & 30 & .000 \\
\hline
\end{tabular}

Berdasarkan tabel 3 menunjukkan nilai rata - rata pretest dan nilai rata-rata posttest hasilnya sama dengan ketiga RPP yang telah analisis, nilai signifikannya sebesar 0,000,nilai Sig (2-tailed) $(0,000)<$ $\alpha / 2 \alpha / 2(0,025)$ maka Ho ditolak. Hal ini menunjukkan dari ketiga RPP terdapat pengaruh model pembelajaran generatif terhadap hasil belajar jika di tinjau dari nilai hasil belajar pretest dan posttest.

\section{Hasil uji n-Gain}

Hasil uji n-Gain diperoleh dengan menggunakan perhitungan hasil pretest dan hasil posttest. Presentase nilai n-Gain hasil belajar dapat dijelaskan sebagai berikut.

n-Gain rata-rata Hasil Belajar RPP 1
n-Gain rata-rata hasil belajar RPP 1 dengan menggunakan model pembelajaran generatif pada materi ikatan kimia peserta didik SMK Negeri 3 Jayapura pada Gambar1:

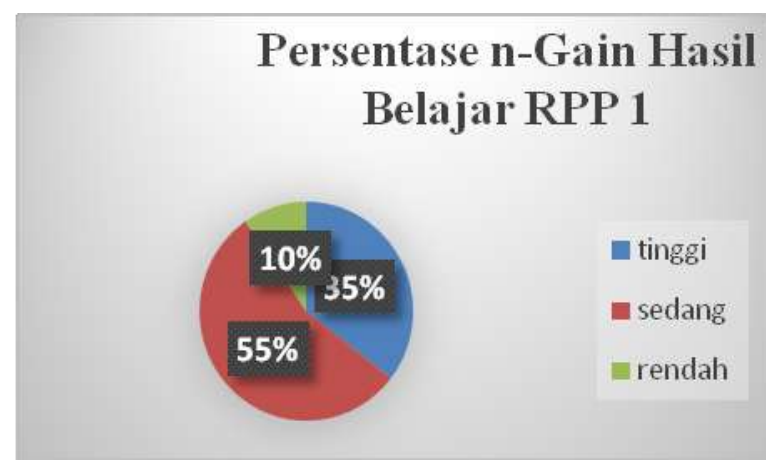

Gambar 1. Persentase n-Gain Hasil Belajar RPP 1.

Berdasarkan gambar 1 sebanyak $55 \%$ nilai n-Gain menunjukkan peningkatan hasil belajar yang sedang, $10 \%$ rendah dan $35 \%$ tergolong tinggi. Berdasarkan hasil pengujian hipotesis, data 
yang didapatkan dalam penelitian ini sesuai dengan beberapa teori model pembelajaran adalah suatu perencanaan atau suatu pola yang digunakan sebagai pedoman dalam merencanakan pembelajaran di kelas atau pembelajaran tutorial. (dalam Trianto 2012) bila dihubungkan dengan model pembelajaran generatif adalah suatu model pembelajaran berbasis konstruktivisme, model pembelajaran ini megharapkan peserta didik memiliki pengetahuan, kemampuan serta keterampilan untuk mengkontruksi/ membangun pengetahuan secara mandiri. Dengan pengetahuan awal (prior knowledge) yang telah di miliki sebelumnya dan menghubungkannya dengan konsep yang dipelajari, akhirnya siwa mampu mengkonstruksi pengetahuan baru. Proses kontruksi (membangun) dilakukan terus menerus dengan cara mengatur, menyusun, dan menata ulang. Pembelajaran konstruktivistik peserta didik dibiasakan untuk memecahkan masalah, menemukan sesuatu, dan mengkontruksi pengetahuan peserta didik tersebut (Lisna $\mathrm{N}$ 2017). Besarnya pengaruh model pembelajaran generatif terhadap hasil belajar mencapai 0,407 dengan rata - rata nilai peserta didik dari ketiga rencana pelaksanaan pembelajaran yaitu 80 tidak berbeda jauh dengan hasil belajar peserta didik, yaitu pada RPP 1 71, RPP 2 82, dan RPP 3 85. Nilai rata - rata hasil belajar menunjukkan dipengaruhi oleh model pembelajaran generatif.

Untuk mengetahui pengaruh model pembelajaran generatif terhadap hasil belajar jika di tinjau dari hasil belajar pretest dan postest menggunakan uji t-test berpasangan (pairent sample t-test), uji ini digunakan untuk melihat perbedaan antara rata - rata nilai sebelum di beri perlakuan (pretest) dan setelah diberikan perlakuan (postest) dengan menggunakan model pembelajaran. Uji t-test ini di analisis pada setiap RPP dengan nilai Sig (2-tailed) $(0,000)<\alpha / 2(0,025)$ maka Ho ditolak. Berdasarkan hasil analisis pada RPP 1 di dapatkan nilai sig 0,000 nilai ini $<\alpha / 2$ $(0,025)$ menunjukkan bahwa hasil uji t-test pada RPP 1 terdapat pengaruh model pembelajaran terhadap hasil belajar, pada RPP 2 berdasarkan hasil analisis t-test didapatkan nilai sig sebesar 0,000 menunjukkan bahwa nilai sig $<\alpha / 2(0,025)$ menunjukkan bahwa RPP 2 terdapat pengaruh pada model pembelajaran terhadap hasil belajar, pada RPP 3 berdasarkan hasil analisis t-test di dapat nilai sig sebesar 0,004 menunjukkan bahwa nilai sig $<\alpha / 2 \quad(0,025)$ terdapat pengaruh model pembelajaran terhadap hasil belajar. Berdasarkan rata - rata dari ketiga RPP untuk nilai pretest dan postest di analisis menggunakan t-test di dapatkan nilai sig sebesar $0,000 \mathrm{sig}<\alpha / 2(0,025)$. Dapat di disimpulkan bahwa pengaruh model pembelajaran terhadap hasil belajar 
jika di tinjau dari nilai hasil pretest dan postest menunjukkan bahwa terdapat pengaruh model pembelajaran generatif terhadap hasil belajar kimia materi ikatan kimia kelas X otomotif di SMK Negeri 3 Jayapura.

Tujuan pembelajaran akan tercapai dengan model pembelajaran yang tepat. Indikator tercapainya suatu tujuan pembelajaran di tandai dengan hasil belajar peserta didik . Hasil belajar peseta didik di tunjukkan dengan penguasaan konsep peserta didik terhadap konsep - konsep ikatan kimia yang diajarkan. Konsep ikatan kimia terjadi karena ada serah terima elektron, misalnya peristiwa korosi. Korosi adalah penurunan / degradasi kualitas material akibat interaksi dengan lingkungan (Tiurlina Siregar 2013). Hasil analisis uji n-Gain seperti gambar terlihat bahwa semua peserta didik mengalami peningkatan belajar, baik itu pada RPP 1, RPP 2, dan RPP 3 tetapi ada perbedaan angka persentasenya. Analisis n-Gain dilakukan untuk melihat tinggi rendahnya peningkatan hasil belajar peserta didik sebelum dan setelah pembelajaran menggunakan model pembelajaran generatif. Data nilai n-Gain hasil belajar RPP 1 di tunjukkan pada gambar 1 dimana nilai n-Gain masih di dominasi oleh kategori tinggi ( nilai $\mathrm{n}$-Gain $>0,7$ ) rata rata nilai $\mathrm{n}$-Gain pada RPP 1 sebesar 0,621 dan masih terdapat nilai $\mathrm{n}$-Gain yang rendah sebesar $10 \%$. Hal tersebut dikarenakan peseta didik masih belum terbiasa mengikuti pembelajaran dengan model pembelajaran generatif, selain itu peserta didik dituntut untuk menguasai materi tentang ikatan kimia, ikatan ion dan ikatan kovalen sehingga peserta didik yang belum terbiasa akan merasa kesulitan. n-Gain Hasil Belajar RPP 2.

Untuk melihat persentase kategori nilai $\mathrm{n}$-Gain hasil belajar peserta didik tersebut dapat dilihat pada Gambar 2:

\section{Persentase n-Gain Hasil Belajar RPP 2}

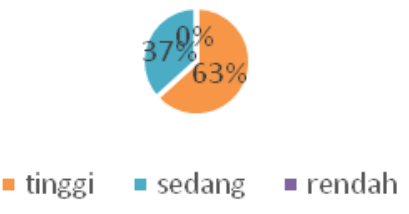

Gambar 2. Menunjukkan persentase n-Gain Hasil Belajar RPP 2.

Berdasarkan gambar 2 nilai $\mathrm{n}$-Gain yang termasuk dalam kategori tinggi sebanyak tinggi sebanyak 63\%, kategori sedang sebanyak $37 \%$, dan dalam kategori rendah sebesar $0 \%$. Pada RPP 2 peningkatan hasil belajar peserta didik akan semakin meningkat seperti yang ditunjukkan pada gambar 2 bahwa nilai nGain rata-rata tetap kategori tinggi tetapi nilai n-Gain yang kurang dari 0,3 (kategori rendah) turun hingga $0 \%$ dan kategori sedang turun menjadi $37 \%$. Rata - rata nilai $n$-Gain yaitu sebesar 0,682 . Hal ini terjadi karena peserta didik sudah mulai 
terbiasa dan sudah bisa menyesuaikan dengan mengikuti pembelajaran dengan model pembelajaran generatif serta peserta didik bisa mengkonstruk pengetahuan yang sedang dipelajari.

n-Gain Hasil Belajar RPP 3

Untuk melihat persentase kategori nilai n-Gain hasil belajar RPP 3 di tunjukkan dalam Gambar 3 berikut:

\section{Persentase n-Gain Hasil Belajar RPP3}

$0 \%$

$35 \%$

$65 \%$ 1. ting $\mathrm{i}$ II sedang rendah

Gambar 3. Persentase n-Gain Hasil Belajar RPP 3.

Berdasakan gambar 3 dapat dilihat bahwa presentase n- Gain di dominasi oleh kategori tinggi sebesar $65 \%$, sedangkan kategori sedang sebesar 35\% dan kategori rendah sebesar 0\%. Hasil Uji n-Gain Hasil Belajar 1, 2 dan 3. Hasil Uji n-Gain Hasil belajar 1, 2 dan 3. Hasil peningkatan yang lebih baik terlihat pada RPP 3 ditunjukkan dalam Gambar 3 dimana peningkatan hasil belajar peserta didik tergolong tinggi. Angka peningkatan rata-ratanya mencapai 0,793 dari batas atas kriteria 0,70 (tinggi ). Nilai n-Gain hasil belajar peserta didik yang kurang dari 0,3 ( kategori rendah ) masih terdapat yaitu sebanyak $0 \%$.
Berbeda dengan pembelajaran RPP 1 dan RPP 2, pembelajaran RPP 3 dilakukan praktikum dengan materi kepolaran senyawa kovalen, sehingga peserta didik jauh lebih bersemangat dan antusias terhadap materi yang dipelajari pada pertemuan ketiga, sehingga terlihat peningkatan hasil belajar peserta didik semakin tinggi. Hal ini disebabkan bahwa model pembelajaran generatif pada materi kepolaran senyawa kovalen cocok digunakan karena terbukti dapat meningkatkan hasil belajar peserta didik kelas X SMK Negeri 3 Jayapura.

Untuk hasil uji n-Gain rata-rata hasil belajar pada RPP 1, 2 dan 3 dapat dilihat pada Gambar 4 berikut:

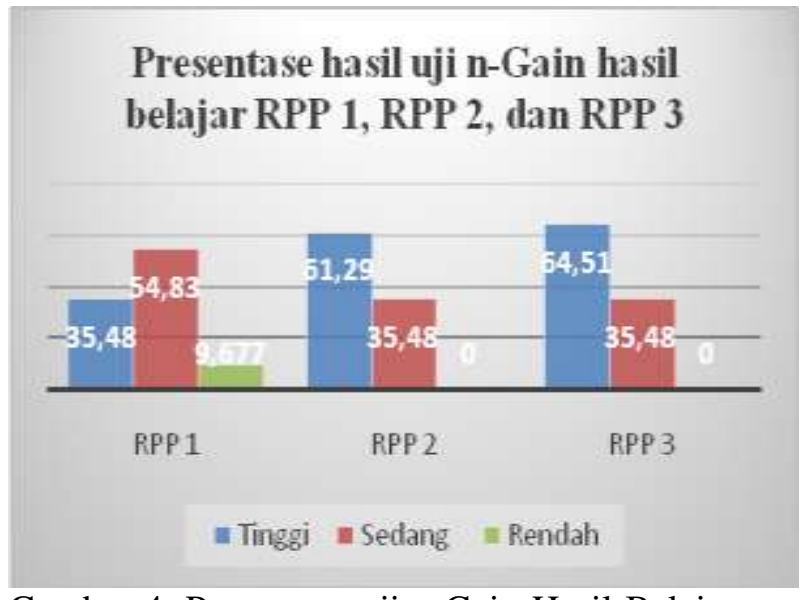

Gambar 4. Presentase uji n-Gain Hasil Belajar RPP 1, RPP 2 dan RPP 3.

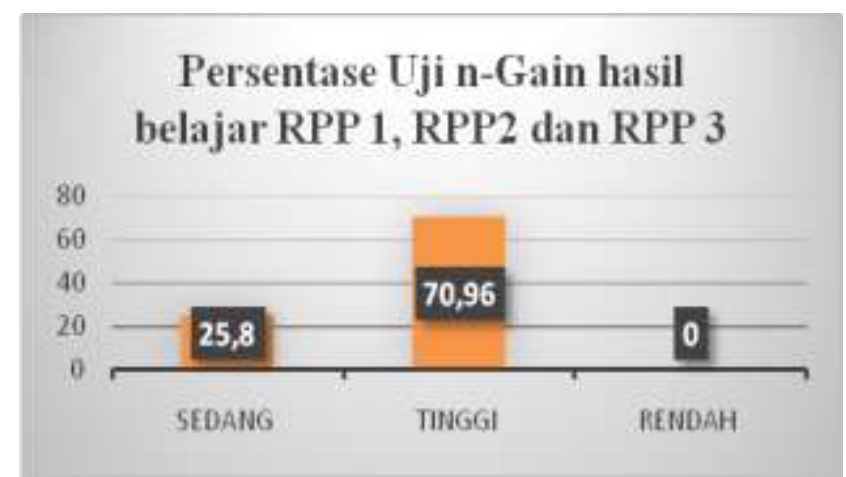

Gambar 5. Uji n-Gain Rata-rata dari ketiga RPP. 
Berdasarkan Gambar 5 dapat dilihat bahwa peningkatan nilai $\mathrm{n}$-Gain rata-rata dari hasil belajar 1 sampai 3 semakin membaik dengan meningkatnya nilai nGain dalam kategori tinggi. Pada Gambar 5 menunjukkan bahwa n-Gain rata-rata dari ketiga RPP meningkat dalam kategori tinggi. Hal ini sejalan dengan pendapat dari Subiyanto dan Tiurlina Siregar (2018), bahwa modul pembelajaran dapat meningkatkan hasil belajar kimia. Jadi model pembelajaran generatif cukup efektif dalam meminimalisir miskonsepsi maupun meningkatkan hasil belajar peserta didik, sehingga jika dilakukan dalam jangka waktu yang lama akan menghasilkan peningkatan hasil belajar yang lebih baik serta meningkatkan pemahaman konsep peseta didik tentang kimia. Penelitian ini menguatkan penelitian terdahulu yang dilakukan oleh Suryanti Lily (2009), dimana model pembelajaran generatif dapat meningkatkan kemampuan berpikir kritis dan hasil belajar peserta didik di bandingkan pembelajaran konvensional. Hal ini menjadi masukan yang bagus bagi guru mata pelajaran kimia khususnya di lingkungan SMK Negeri 3 Jayapura guna menerapkan model pembelajaran generatif dan model pembelajaran lain serta metode-metode pembelajaran yang menarik agar peserta didik tidak merasa bosan saat proses pembelajaran di sekolah.

\section{SIMPULAN DAN SARAN SIMPULAN}

Ada pengaruh yang signifikan antara penggunaan model pembelajaran generatif terhadap hasil belajar kimia pada materi ikatan kimia peserta didik kelas $\mathrm{X}$ otomotif SMK Negeri 3 Jayapura. Peningkatan hasil belajar kimia pada materi ikatan kimia (n-Gain) yang menggunakan model pembelajaran generatif pada peserta didik kelas $\mathrm{X}$ otomotif SMK Negeri 3 Jayapura dengan niali $\mathrm{n}$-Gain rata-rata RPP 1 sebesar 0,62 , RPP 2 sebesar 0,68 dan RPP 3 sebesar 0,79. Nilai $\mathrm{n}$-Gain rata-rata dari RPP 1 , RPP 2, dan RPP 3 sebesar 0,71 ( kategori tinggi ).

\section{SARAN}

Guru dapat menggunakan model pembelajaran generatif untuk meningkatkan hasil belajar kimia pada materi ikatan kimia. Penelitian yang dilakukan peneliti pada jenjang SMA/SMK dengan materi ikatan kimia, maka perlu dilakukan penelitian lebih lanjut dengan menggunakan model pembelajaran generatif untuk materi kimia yang lain.

\section{UCAPAN TERIMA KASIH}

Kami ucapkan terimaksih kepada Kepala Sekolah SMK Negeri 3 Jayapura yang telah mendukung dan memberi tempat sehingga penelitian ini dapat berjalan denhan baik, Kepada Program Studi Magister Pendidikan IPA kerja 
samanya dengan Sekolah SMK Negeri 3 Jayapura.

\section{DAFTAR PUSTAKA}

Lily, S, 2009, Penerapan model pembelajaran generatif untuk meningkatkan kemampuan berpikir dan hasil belajar fisika peserta didik, Malang, Universitas Negeri Malang;

Lisna, N, 2017, pengaruh model pembelajaran generatif terhadap pemahaman konsep peserya didik pada materi laju reaksi, fakultas ilmu tarbiyah keguruan universitas islam negeri syarif hidayatullah: Jakarta;

Setianingsih, A, 2018, bahan ajar kimia sistem periodik unsur dan ikatan kimia berbasis konteks kendaraan untuk peserta didik SMK teknik otomotif, Yogyakarta, Fakultas Matematika dan Ilmu Pengetahuan Alam UNY;
Subiyanto, Tiurlina Siregar 2018, Pengembangan Model Pembelajaran Kimia Pada Materi Sistem Periodik Unsur Berbasis Kearifan Lokal Papua Peserta Didik kelas X SMA Negeri 4 Jayapura, Jurnal Ilmu Pendidikan Indonesia, Vol. 6 No 3, halaman 71-82;

Tiurlina Siregar, 2013, Studi Laju Korosi Dan Mekanisme Inhibisi Aluminium Murni Menggunakan Natrium Sitrat, Journal of Chemistry, ISSN 19079850 , Vol. 7 N0.1 Januari 2013, unud.ac.id;

Trianto, (2007). Model- model pembelajaran inovatif berorientasi kontruktivistik, Jakarta, Prestasi Pustaka;

Wena, M, (2008), strategi pembelajaran inovatif kontemporer suatu tinjauan konseptual operasional, Malang Bumi Aksara. 